\title{
ANALISIS PERUBAHAN GARIS PANTAI AKIBAT PENGARUH PEMASANGAN GROPOZAG (Studi Kasus Pantai Neuhen, Aceh Besar)
}

\author{
Sofyan Andre ${ }^{1)}$, Eldina Fatimah ${ }^{2)}$, Syamsidik ${ }^{3)}$ \\ ${ }^{1)}$ Magister Teknik Sipil, Fakultas Teknik, Universitas Syiah Kuala \\ ${ }^{2,3)}$ Jurusan Teknik Sipil, Fakultas Teknik, Universitas Syiah Kuala \\ Email: sofyan.andre.sikumbang@gmail.com ${ }^{1}$, eldinafatimah@unsyiah.ac.id ${ }^{21}$, \\ syamsidik@ unsyiah.ac.id $^{3)}$
}

DOI: http://dx.doi.org/10.29103/tj.v11i2.458

(Received: December 2020 / Revised: January 2021 / Accepted: May 2021)

\begin{abstract}
Abstrak
Pada saat sekarang ini banyak penelitian dan perlakuan yang telah dilakukan dan diteliti oleh para ahli untuk memperkecil dampak buruk yang terjadi diakibatkan oleh erosi dan sedimentasi diantaranya adalah groin. Bangunan pantai dengan jenis groin yang sudah sering digunakan pada pantai-pantai di daerah Indonesia pada umumnya adalah groin susunan batu gajah dengan model groin solid (impermeable) di mana tidak ada air yang dapat lewat dari tubuh groin tersebut. Berbagai tipe, konfigurasi, jenis material, dan tinggi groin yang sudah diterapkan di Aceh, salah satunya adalah groin tipe zigzag berpori (gropozag). Gropozag telah mengalami berbagai kajian baik model fisik di laboratorium maupun numerik. Namun untuk aplikasi kinerjanya di lapangan masih jarang dilakukan. Paper ini bertujuan untuk mengetahui pengaruh pemasangan bangunan gropozag terhadap perubahan garis pantai Neuheun. Gropozag dibuat dengan susunan kubus yang disusun dengan pola zig-zag. Ukuran kubus perunitnya adalah $1 \mathrm{~m} \times 1 \mathrm{~m} \times 1 \mathrm{~m}$ dengan beberapa lubang disisi kiri-kanannya. Sisi atas terbuka dan sisi bawah tertutup penuh tanpa adanya lubang. Beberapa unit kubus dirangkai menjadi satu rangkaian single groin dan diletakkan tegak lurus pantai. Pengamatan yang dilakukan adalah kondisi sebelum pemasangan gropozag tahun 2017 dan setelah pemasangan gropozag tahun 2019. Hasil dari pengukuran yang dilakukan selama 1 tahun menunjukkan bahwa pengaplikasian gropozag memberikan pengaruh pada perubahan garis pantai di mana terlihat pada pantai yang berada di kiri dan kanan Gropozag. Erosi yang terjadi pada pantai bagian kiri yang disebabkan oleh gelombang yang datang dari arah Timur laut lebih besar dibandingkan dengan erosi pada pantai yang berada di posisi kanan Gropozag.
\end{abstract}

Kata kunci: perubahan garis pantai, sedimentasi, erosi, groin, gropozag

\begin{abstract}
At the present time, a lot of researchs and treatments have been carried out by experts to minimize the bad effects due to erosion and sedimentation, including the application of groin. Beach structure of the groyne generally used on the Indonesia beaches is groin solid model (impermeable) in which no water can pass the groin. The various types, configuration, material, and height of groin have been applied in Aceh. One of the types is porous zig-zag type groin (gropozag). This type had been tested both as physical model in the laboratory and numerical model. However, the performance application in the field had been rarely carried out. This paper aims to determine the effect of the gropozag application on the coastline changes in the
\end{abstract}


Neuheun Beach. The groin was made of cubes arranged in a zigzag pattern. The size of a unit cube was $1 \mathrm{~m} \times 1 \mathrm{~m} \times 1 \mathrm{~m}$ with several holes on either side. The upper side was open and the bottom side was completely closed without any holes. Several cube units were assembled into a single groyne series and placed perpendicular to the coast. The observation carried out was without gropozag condition year 2017 and after gropozag installation tear 2019. Output of the research showed that the Gropozag application affected the coastline changes in the left and right area of the Gropozag. The erosion carried out in the left side of the gropozag which was affected by the waves from northeast was higher than the right side of the gropozag.

Keywords: coastline change, sedimentation, erosion, groin, gropozag

\section{Latar Belakang}

Maju dan mundurnya garis pantai tidak akan pernah terlepas dari dua fenomena yang sudah familiar yaitu erosi dan sedimentasi. Erosi terjadi dikarenakan sedimen yang ada dibawa oleh gelombang kembali kelaut dan menyebabkan mundurnya garis pantai, berkebalikan dengan sedimentasi di mana gelombang datang membawa sedimen dan terjadi penumpukan sehingga garis pantai terus maju (Triatmodjo, 2012). Pada saat sekarang ini banyak penelitian dan perlakuan yang telah dilakukan dan teliti oleh para ahli untuk memperkecil dampak buruk yang terjadi dengan berusaha mengontrol pasir yang selalu bergerak dinamis untuk melakukan pergerakan sesuai dengan keinginan dan tujuan para ahli (Mohanty et al., 2012).

Banyak rekayasa yang telah dilakukan untuk mengontrol perubahan morfologi pantai akibat proses erosi dan sedimentasi yang terjadi. Meskipun demikian seluruh rekayasa yang dilakukan memiliki dampak positif dan negatif terhadap pantai itu sendiri (Ibrahim, 2014). Rekayasa terhadap pergerakan sedimen menggunakan bangunan pantai jenis groin adalah salah satu upaya untuk menjaga stabilitas garis pantai (Yustian et al., 2016).

Terdapat banyak penelitian tentang pengaruh pemasangan groin dan akibat yang ditimbulkan di beberapa pantai di Indonesia. Beberapa penelitian tersebut diantaranya perubahan garis pantai di Pantai Sanur sebagai efek dari pemasangan groin (Efendi, 2016), pengaruh sedimentasi pada groin di kawasan perairan Kabupaten Demak (Pranoto and Atmodjo, 2016), serta perubahan garis pantai akibat bangunan pengaman pantai (groin) di pantai Sumatera Barat (Hamidi et al., 2019).

Bangunan pantai dengan jenis groin yang sudah sering digunakan pada pantai-pantai di daerah Indonesia pada umumnya adalah groin susunan batu gajah dengan model groin solid di mana tidak ada air yang dapat lewat dari tubuh groin tersebut, adapun groin tipe permeable yang sudah lazim adalah tiang berbahan baik kayu maupun beton yang dipancang (Fatimah and Irawan, 2012). Kajian groin tipe zigzag telah dilakukan oleh (Fatimah et al., 2015) dengan menggunakan skala baik berupa model fisik di Laboratorium Sungai dan Pantai Fakultas Teknik Unsyiah maupun model numerik. Aplikasi langsung di lapangan juga telah dilakukan, tetapi gropozag difungsikan sebagai pemecah gelombang (breakwater) lepas pantai. Paper ini bertujuan untuk mengetahui pengaruh pemasangan bangunan gropozag terhadap perubahan garis pantai di Neuheun. 


\section{Metode Penelitian}

\subsection{Lokasi}

Area lokasi yang menjadi fokus pada paper ini adalah pantai yang berada di Desa Neuhen Kecamatan Mesjid Raya Kabupaten Aceh Besar yang terletak pada koordinat UTM Zona 46767433.43 E, 624839.84 N. Bagian barat Pantai berbatasan dengan bukit, sedangkan bagian selatan berbatasan dengan kompleks Balai Perikanan dan Budidaya Air Payau Ujung Batee Lokasi II. Lokasi ini biasanya digunakan masyarakat sebagai tempat wisata juga tempat untuk melakukan kegiatan memancing. Pada lokasi kegiatan telah terpasang bangunan pelindung pantai existing yaitu revetment pantai. Lokasi dapat dilihat pada Gambar 1.

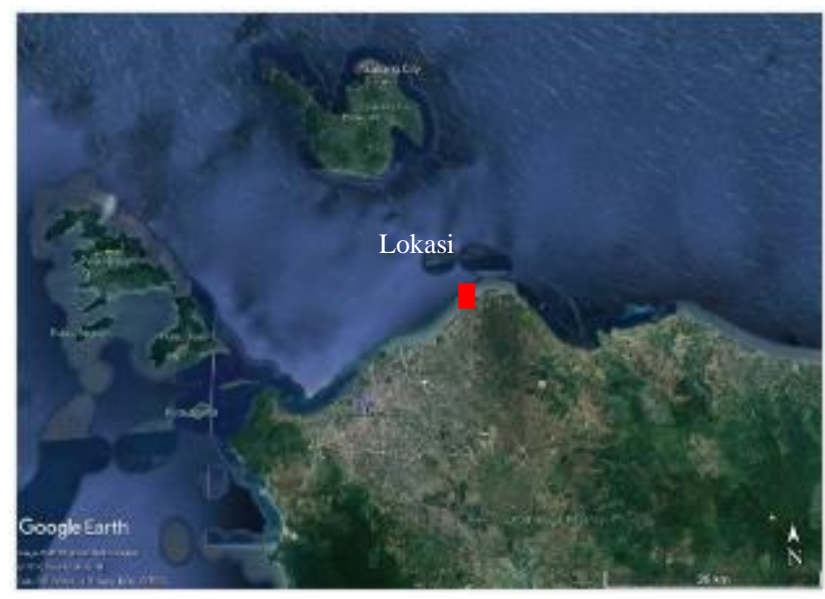

Gambar 1 Lokasi Pengamatan

\subsection{Objek}

Fokus objek adalah bangunan groin dengan tipe permeabel yang sudah di bentuk sedemikian rupa hingga dapat dibongkar pasang. Ukuran per-unitnya adalah $1 \mathrm{~m} \times 1 \mathrm{~m} \times 1 \mathrm{~m}$ dengan beberapa lubang di sisi kiri-kanannya. Sisi atas terbuka dan sisi bawah tertutup penuh tanpa adanya lubang. Groin ini disusun dari bentuk satuannya menjadi sebuah bangunan groin yang solid, disusun dengan pola zig-zag seperti diperlihatkan pada Gambar 2.

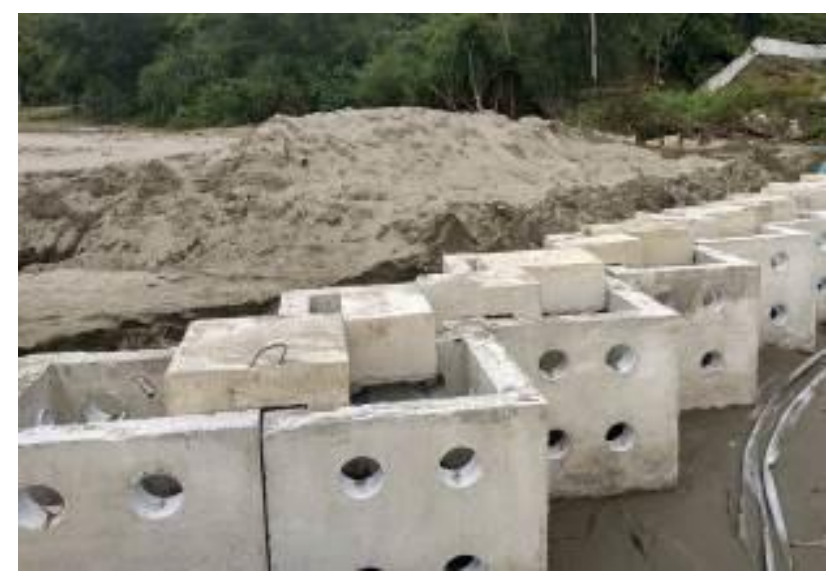

Gambar 2 Groin berporos pola zigzag (gropozag) 
Sejumlah 20 buah unit gropozag yang digunakan untuk membentuk satu kesatuan groin tunggal dan diletakkan tegak lurus pantai. Hanya satu seri groin saja yang dibangun dan diamati perubahan garis pantai khususnya di sekitar bangunan.

\subsection{Pengumpulan data}

Data yang dikumpulkan berupa data primer yaitu data pemetaan. Data pemetaan merupakan data yang diambil dengan melakukan pengukuran sipat datar. Pengukuran ini meliputi daratan dan laut yang diukur secara manual menggunakan alat ukur sipat datar (waterpass) dengan bantuan bak ukur. Pada satu penampang pengukuran dibagi menjadi 16 bagian yang akan menjadi profil melintang (croos section) yang dapat dilihat pada Gambar 3.

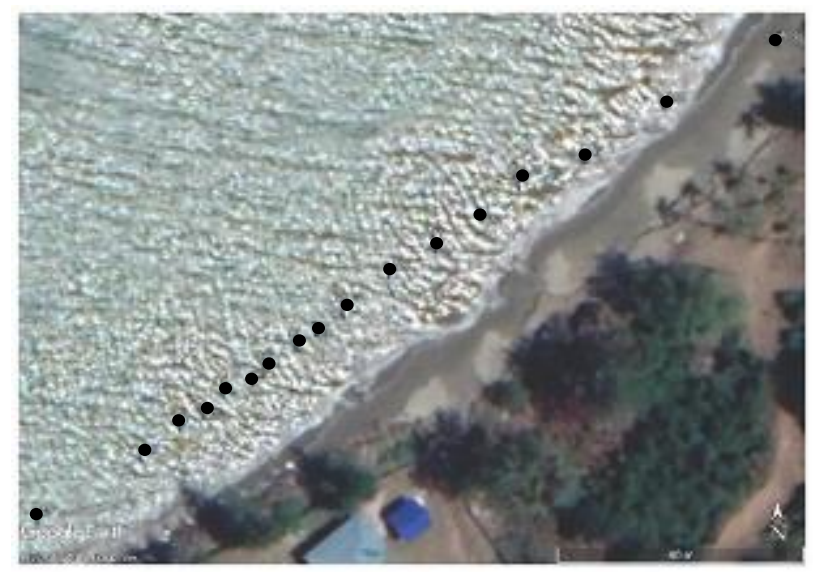

Gambar 3 Patok pengukuran pemetaan

Paper ini menitik beratkan pada perubahan garis pantai, maka diperoleh jarak batasan pengamatan berada pada jarak $60 \mathrm{~m}$ sampai dengan 800 -meter dan skala waktu dari harian, musiman, sampai dengan tahunan. Luasan area pengamatan adalah lebar $180 \mathrm{~m}$ dan panjang $85 \mathrm{~m}$. Pengambilan data atau periode pengambilan data dilakukan dua kali dalam sebulan atau dua minggu sekali yang nantinya akan diakumulatifkan pada setiap pengukuran.

\subsection{Analisis Data}

Survey topografi dilakukan untuk menggambarkan secara visual kondisi bentuk rupa permukaan tanah pada lokasi. Hasil ini berupa kontur tanah yang melambangkan tinggi rendahnya kawasan tersebut. Tinggi rendahnya suatu tempat diperoleh dari pembacaan pada bak ukur dengan menggunakan alat ukur yaitu waterpass. Lokasi titik pengamatan pengukuran topografi direncanakan terbagi menjadi 16 bagian, yang akan menjadi patok pengukuran. Hasil pengukuran topografi tersebut disajikan pada Tabel 1. Untuk menetukan titik ikat elevasi seluruh pengukuran akan diikat ke satu titik referensi elevasi pada lokasi kegiatan, yaitu pada patok BM (Bench Mark) milik PLN dengan elevasi Z = + 4,824 mdp.

Analisis perubahan garis pantai dilakukan dengan melihat perubahan yang terjadi sebelum pemasangan gropozag dan setelah pemasangan gropozag. Analisis ini meliputi perubahan yang terjadi akibat erosi yang menyebabkan mundurnya 
garis pantai serta perubahan akibat sedimentasi yang menyebabkan majunya garis pantai. Pada pelaksanaan di lapangan, terlebih dahulu diamati posisi garis pantai sebelum pemasangan gropozag. Setelah pemasangan gropozag, maka dalam kurun waktu tertentu diamati kondisi garis pantai di bagian sebelah kanan konstruksi gropozak maupun kondisi di bagian kiri konstruksi gropozak yang telah dipasang, apakah terjadi erosi ataupun sedimentasi pada sisi kiri dan kanan konstruksi.

Tabel 1 Hasil pengukuran topografi

\begin{tabular}{ccc}
\hline No & Nama Titik Pengukuran & $\begin{array}{c}\text { Ketinggian } \\
(\mathbf{M d p l})\end{array}$ \\
\hline 1. & Titik 1 & 0,778 \\
\hline 2. & Titik 2 & 1,828 \\
\hline 3. & Titik 3 & 1,875 \\
\hline 4. & Titik 4 & 1,895 \\
\hline 5. & Titik 5 & 2,319 \\
\hline 6. & Titik 6 & 1,776 \\
\hline 7. & Titik 7 & 1,776 \\
\hline 8. & Titik 8 & 1,748 \\
\hline 9. & Titik 9 & 1,696 \\
\hline 10. & Titik 10 & 1,581 \\
\hline 11. & Titik 11 & 1,635 \\
\hline 12. & Titik 12 & 1,675 \\
\hline 13. & Titik 13 & 1,626 \\
\hline 14. & Titik 14 & 1,845 \\
\hline 15. & Titik 15 & 1,793 \\
\hline 16. & Titik 16 & 1,876 \\
\hline
\end{tabular}

\subsection{Pemasangan Unit Gropozag}

Pemasangan dilakukan dengan bantuan alat berat yaitu excavator. Total panjang bangunan gropozag setelah dirangkai adalah $15 \mathrm{~m}$. Kondisi sebelum dan setelah pemasangan gropozag seperti diperlihatkan pada Gambar 4, Gambar 5 dan Gambar 6.

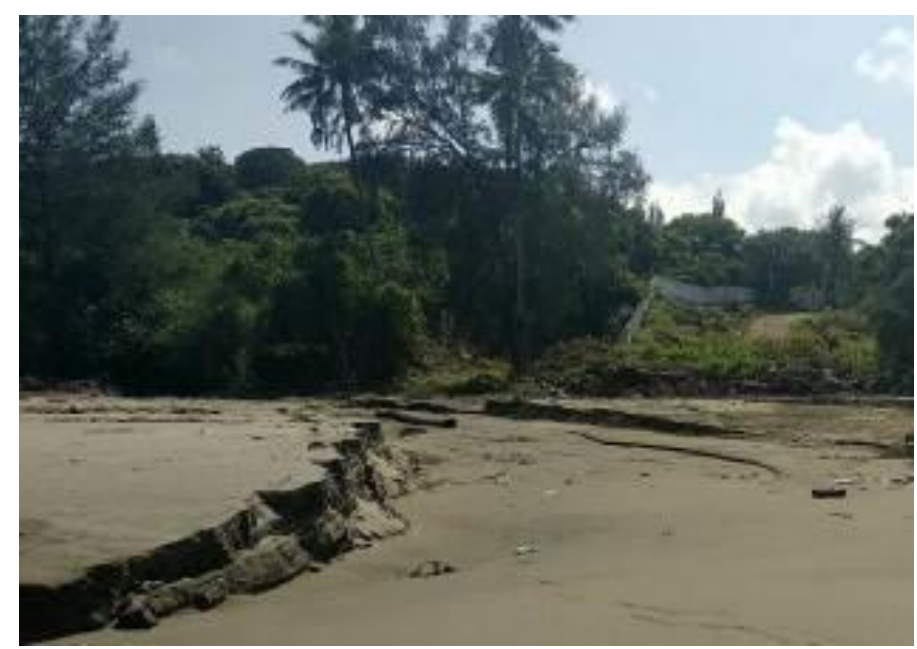

Gambar 4 Lokasi sebelum pemasangan gropozag 
Gropozag diletakkan pada area surf zone yaitu lokasi di mana terjadinya transport sedimen sejajar pantai (longshore sediment transport). Gelombang pecah berkisar antara $2.092 \mathrm{~m}-2.653 \mathrm{~m}$ dengan kedalaman $2.426 \mathrm{~m}-3.078 \mathrm{~m}$ maka diperoleh jarak antara bibir pantai dan posisi gelombang pecah sejauh $59.770 \mathrm{~m}$ sampai dengan $69.950 \mathrm{~m}$. Gambar gropozag yang telah dipasang dapat dilihat pada gambar 6 .

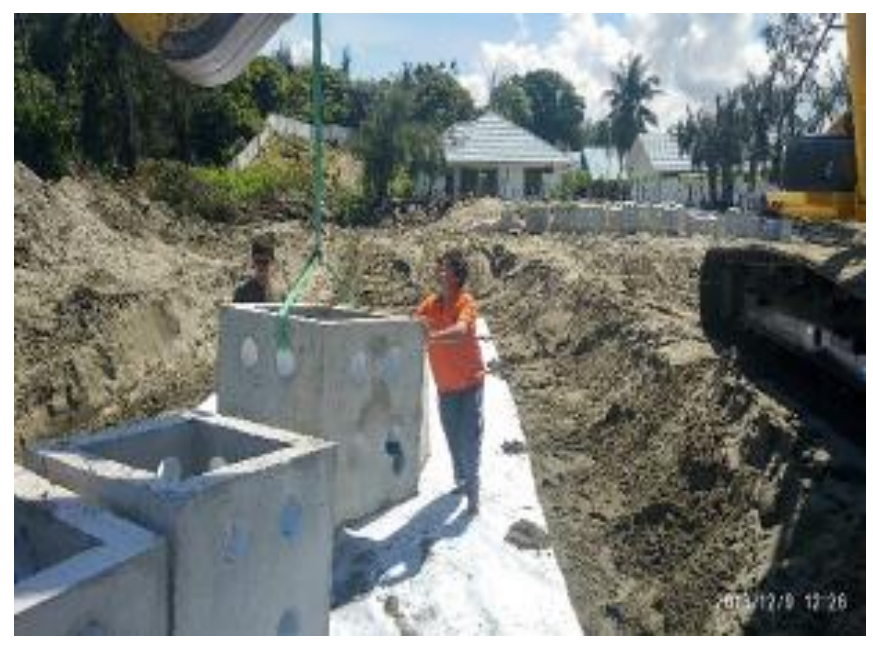

Gambar 5 Pemasangan/perangkaian unit gropozag pada lokasi

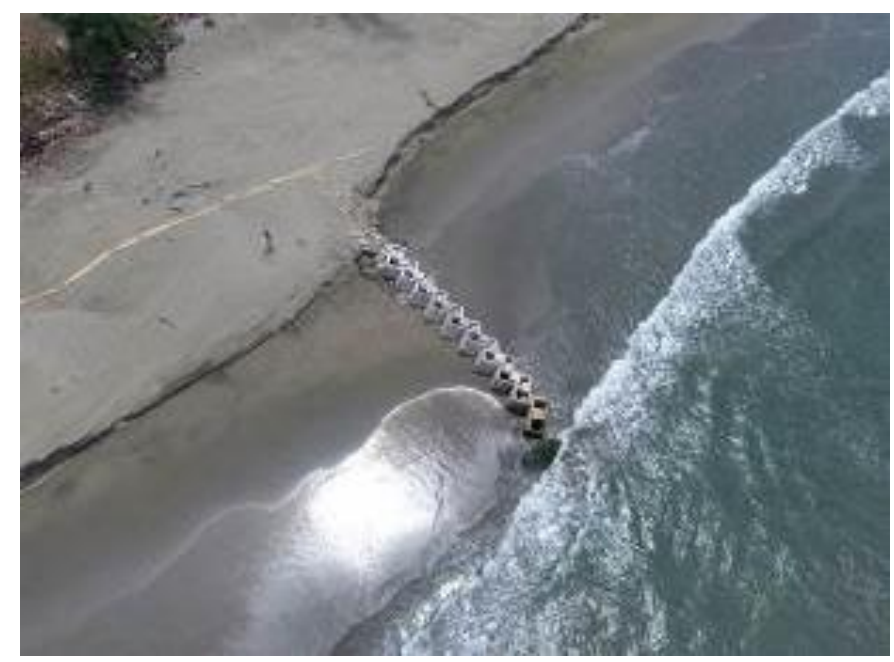

Gambar 6 Lokasi setelah pemasangan gropozag

\section{Hasil dan Pembahasan}

\subsection{Hasil Pemetaan}

Pada proses pemetaan awal peta yang digunakan adalah peta yang bersumber dari penelitian (Pagihariadi et al., 2019) digunakan untuk melihat kondisi sebelum diletakkannya gropozag setelah itu baru dilanjutkan dengan pengukuran seterusnya secara langsung ketika bangunan gropozag telah dipasang. Hasil dari pengukuran dalam bentuk peta topografi untuk awal sebelum dan setelah pemasangan gropozag dapat dilihat pada Gambar 7 dan 8. 


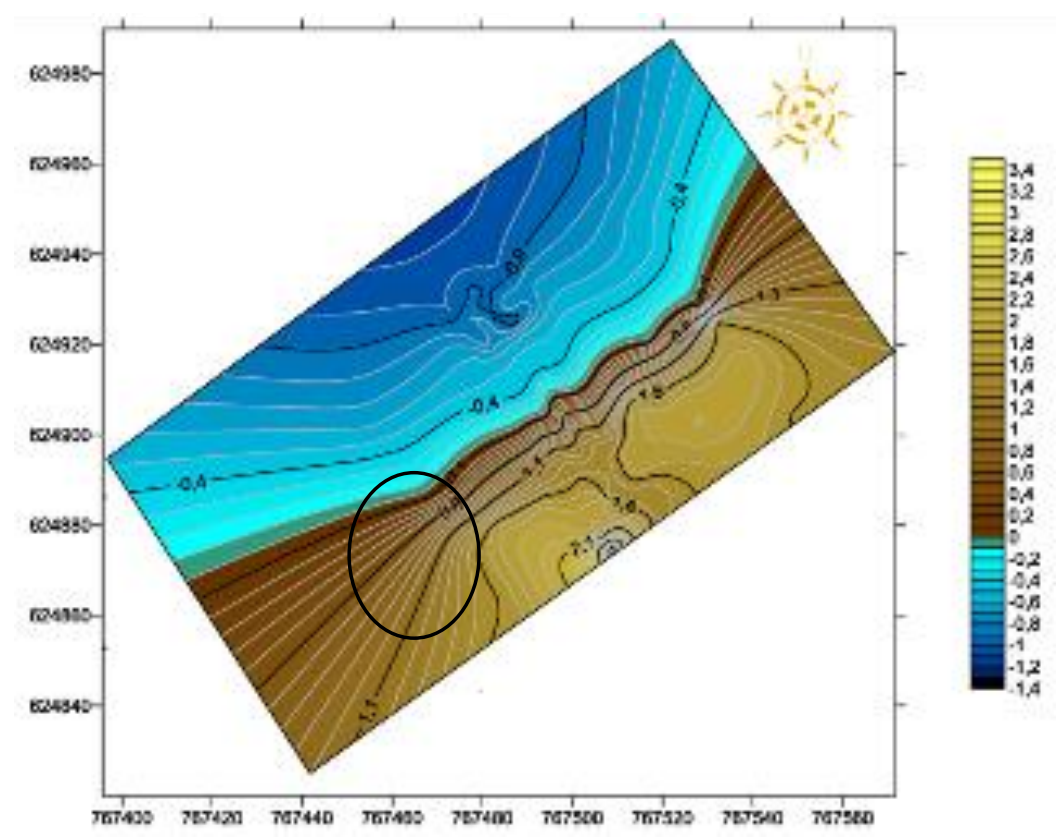

Gambar 7 Peta topografi sebelum pemasangan gropozag pada Desember 2018

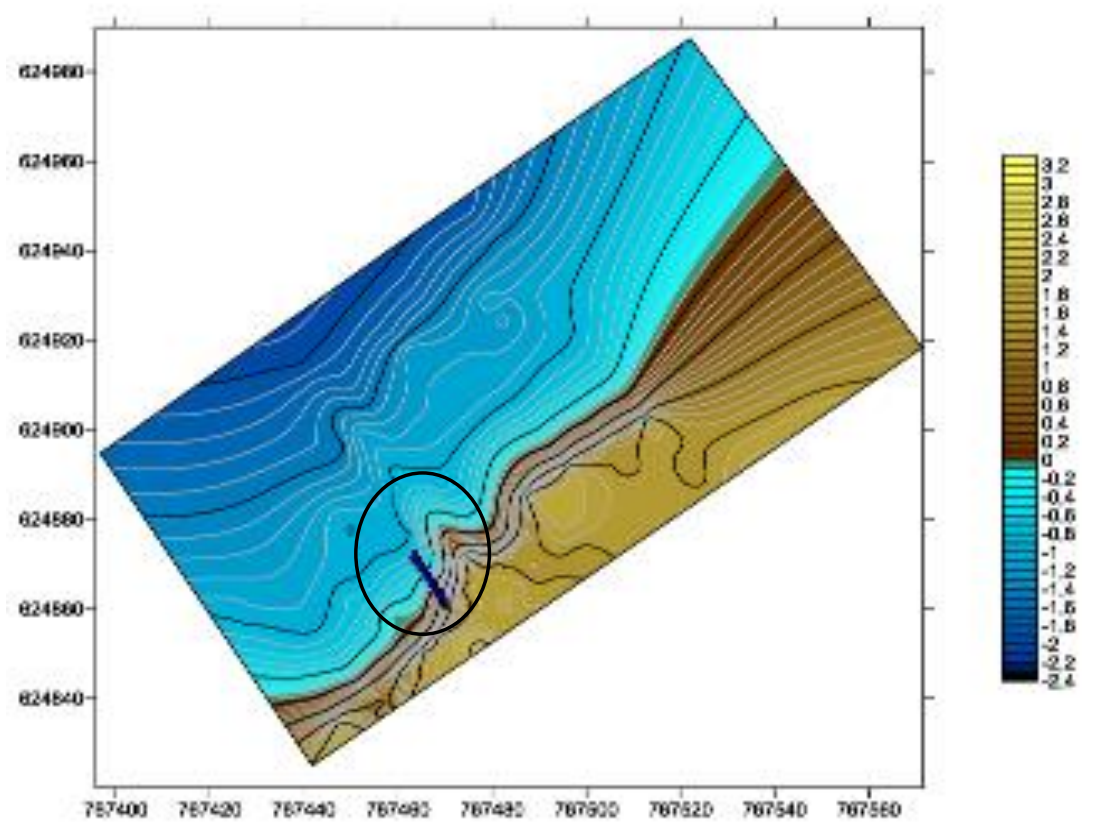

Gambar 8. Peta topografi setelah pemasangan gropozag pada Februari 2019

\subsubsection{Perubahan posisi garis pantai}

Pemilihan lokasi di pantai Desa Neuheun tidak dapat terlepas dari alasan utamanya yaitu di mana pantai dinamis. Pengertian dinamis pada paper ini menitik beratkan pada posisi garis pantai yang terus berpindah-pindah pada setiap waktunya tergantung pada kondisi arah angin dominan yang terjadi. Pernyataan ini dapat di perkuat dengan peta citra udara yang di peroleh dari peta citra udara google earth pada Gambar 9. 


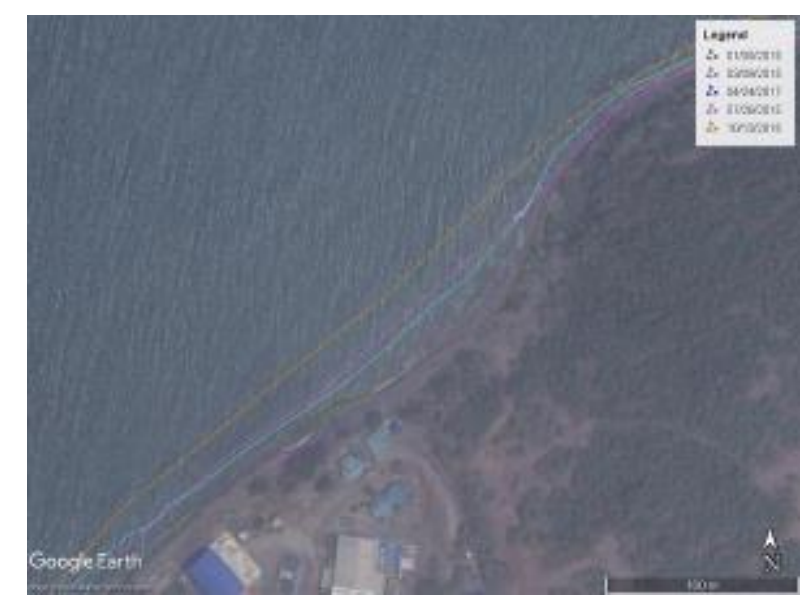

Gambar 9 Perubahan garis pantai pada lokasi pantai Neuheun

\subsubsection{Perubahan Garis Pantai Selama Pengamatan}

Perubahan garis pantai setelah pemasangan gropozag dilakukan melalui pengamatan langsung di lapangan dan hasil pengamatan citra satelit landsat sebelum pemasangan gropozag tahun 2017, saat pemasangan gropozag tahun 2018 dan setelah pemasangan gropozag tahun 2019.

Gambar perubahan tersebut garis pantai didapatkan berdasarkan citra satelit dari tahun 2017 (kondisi sebelum pemasangan gropozag), dan tahun 2019 (setelah pemasangan gropozag). Gambar selengkapnya dapat dilihat pada Gambar 10,11 dan 12.

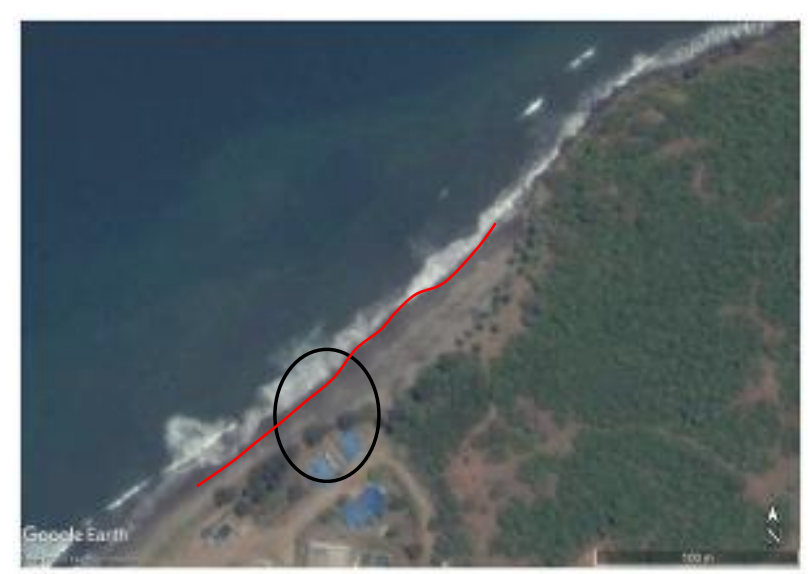

Gambar 10 Kondisi garis pantai sebelum pemasangan gropozag tahun 2017

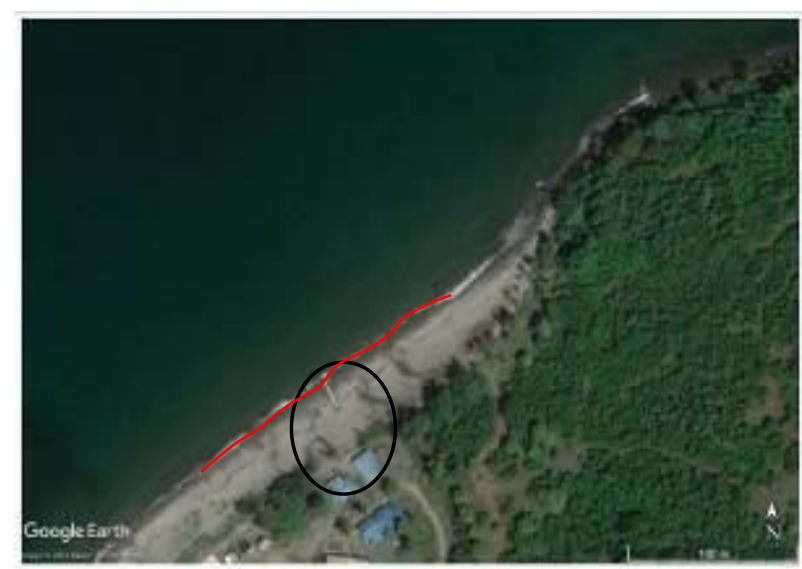

Gambar 11 Kondisi garis pantai awal pemasangan gropozag tahun 2018

Analisis Perubahan Garis Pantai Akibat Pengaruh Pemasangan Gropozag (Studi Kasus Pantai Neuhen, Aceh Besar) - Sofyan Andre, Eldina Fatimah, Syamsidik 


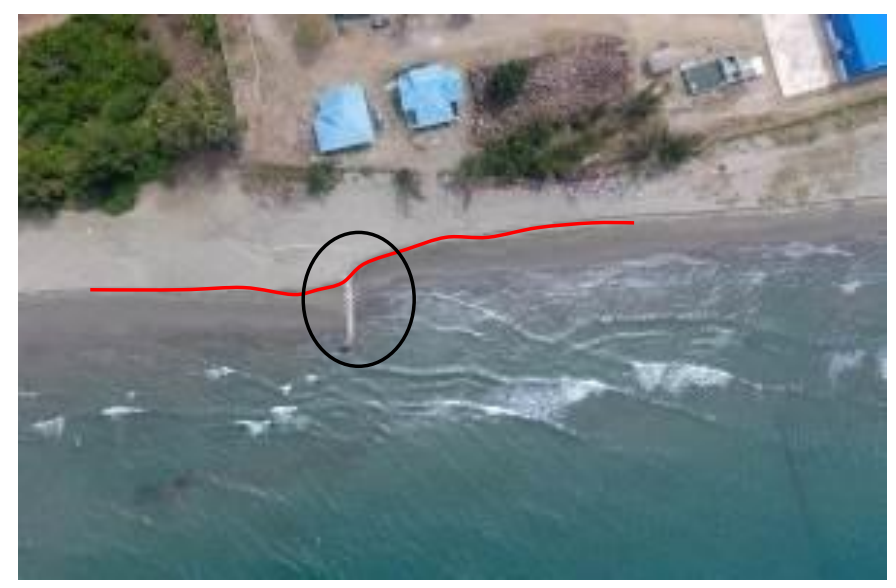

Gambar 12 Kondisi garis pantai setelah pemasangan gropozag tahun 2019

\subsection{Pembahasan}

Berdasarkan pengamatan langsung di lapangan diperoleh bahwa penerapan gropozag sebagai groin tunggal (single groin) di lokasi pengamatan memberikan pengaruh pada perubahan garis pantai yaitu terlihat pada pantai yang berada di bagian kiri dan kanan gropozag. Erosi yang terjadi pada pantai bagian kiri gropozag yang di sebabkan oleh gelombang yang datang dari arah timur laut timur laut lebih besar dari pada erosi yang terjadi di bagian pantai yang berada di kanan gropozag.

Sementara berdasarkan hasil pengamatan menggunakan citra satelit (yaitu tahun 2017 dan 2019) menunjukkan bahwa terjadi perubahan sebelum dan setelah pemasangan gropozag. Kondisi pantai pada daerah tersebut cenderung lurus (seperti ditunjukkan pada Gambar 10). Tetapi setelah 2 (dua) tahun pemasangan gropozag, menunjukkan bahwa wilayah pantai bagian kiri gropozag mengalami erosi lebih besar dibandingkan dengan bagian kanan gropozag (seperti ditunjukkan pada Gambar 11).

Perubahan garis pantai ini tidak terlalu signifikan karena gropozag yang dipasang di daerah tersebut merupakan groyne tunggal dan waktu pengamatannya relatif singkat yaitu hanya 1 (satu) tahun setelah pemasangan gropozag. Walaupun demikian, hasil pengamatan langsung di lapangan dan observasi menggunakan citra satelit menunjukkan hasil yang sama yaitu bagian kiri gropozag mengalami erosi lebih besar dibandingkan dengan bagian kanan gropozag

\section{Kesimpulan dan Saran}

\subsection{Kesimpulan}

Pemasangan gropozag di Pantai Neuhen Kabupaten Aceh Besar memberikan pengaruh terhadap perubahan garis pantai di kawasan tersebut. Sebelum pemasangan gropozag, bentuk perubahan garis pantai pada daerah tersebut cenderung lurus. Setelah pemasangan gropozak selama 1 (satu) tahun menunjukkan bahwa bagian kiri dari gropozag mengalami erosi lebih besar dibandingkan dengan bagian kanan gropozag. Hal ini menggambarkan fungsi gropozak dalam bentuk bangunan groin berfungsi, begitu juga pola dari perubahan pantai yang terjadi di mana pada saat tererosi bagian kiri gropozak tidak tererosi langsung pada pangkal groin hal ini menunjukkan porositas pada gropozak juga bekerja dengan baik. 


\subsection{Saran}

Perubahan garis pantai akibat pemasangan gropozag ini belum dapat dilihat secara signifikan akibat pengamatan baru dilakukan selama 1 (satu) tahun, oleh karena itu, diharapkan pengamatan dapat dilanjutkan oleh peneliti lainnya sehingga diharapkan perubahan garis pantai ini dapat terus tercatat dalam kurun tertentu misalnya 5 - 10 tahun di masa mendatang.

\section{Daftar Kepustakaan}

Efendi, S.S., 2016. Pengaruh Modifikasi Bentuk Groin terhadap Perubahan Garis Pantai Sanur Bali. Tek. Hidraul. 7, 87-98.

Fatimah, E., Arief, Z.A., Aulia, T.B., 2015. The Influence of Single Zigzag Type Porous Groin in the Change of Beach Profile. Procedia Eng. 125, 257-262. https://doi.org/10.1016/j.proeng.2015.11.037

Fatimah, E., Irawan, E.H., 2012. Zig-zag Shape Porous Groin for Beach Stabilization, in: The Eight International Conference on Coastal and Port Engineering in Developing Countries. Presented at the PIANC-COPEDEC VIII, Department of Ocean Engineering, IIT Madras Chenai, India, Chennai, India, pp. 1051-1060.

Hamidi, W.E., Junaidi, A., Hakam, A., Junaidi, J., 2019. Analisa Perubahan Garis Pantai Akibat Bangunan Pengaman Pantai (Groin) di Pantai Salido Pesisir Selatan Sumatera Barat. REKAYASA SIPIL 13, 126-132.

Ibrahim, M.M., 2014. Local Bed Morphological Changes due to Oriented Groins In Straight Channels. Ain Shams Eng. J. 5, 333-341. https://doi.org/10.1016/j.asej.2013.12.006

Mohanty, P.K., Patra, S.K., Bramha, S., Seth, B., Pradhan, U., Behera, B., Mishra, P., Panda, U.S., 2012. Impact of Groins on Beach Morphology: A Case Study near Gopalpur Port, East Coast of India. J. Coast. Res. 279, 132-142. https://doi.org/10.2112/JCOASTRES-D-10-00045.1

Pagihariadi, P., Fatimah, E., Syamsidik, 2019. The Effect of Porous Zigzag Breakwater on the Coastline Changes in Neuhen Village, in: Material Science and Engineering. Presented at the 2nd Aceh International Symposium on Civil Engineering (AISCE), IOP Publishing, Banda Aceh, pp. 1-8.

Pranoto, H.R., Atmodjo, W., 2016. Studi Sedimentasi pada Bangunan Groin di Perairan Timbulsloko, Kabupaten Demak. J. Oceanogr. 5, 86-95.

Triatmodjo, B., 2012. Perencanaan Bangunan Pantai, Kedua. ed. Beta Offset, Yogyakarta.

Yustian, A., Nugroho, D., Ismunarti, D.H., 2016. Studi Efektivitas Groin terhadap Perubahan Garis Pantai di Pantai Teluk Penyu Kabupaten Cilacap. J. Oceanogr. 5, 406-414. 